\title{
Policies, politics and the right to child health in South America
}

\author{
Raul Mercer
}

\section{Correspondence to Dr Raul Mercer, Program of Social Sciences and Health, FLACSO (Latin American School of Social Sciences), Researcher at CISAP (Center for Research in Population Health), Buenos Aires C1026AAC, Argentina; raulmercer@gmail.com}

Received 3 August 2014 Revised 22 August 2014 Accepted 24 August 2014
CrossMark

To cite: Mercer R. Arch Dis Child 2015;100(Suppl 1): s66-s69.

\section{CHARACTERISATION OF A REGION IN TRANSITION}

South America (figure 1) integrates 14 countries, 10 of which belong to the Latin American region and will be part of this analysis. As it happens with the rest of the region, South America has significant social inequities that are expressed in its demographics, health and educational indicators. This region had a historic relevant role in the development health thinking and its social determinants, even before WHO Commission was established, and expressed through the Latin American movement of Social Medicine. ${ }^{1}$

Between 1990 and 2010, all the countries have reduced their infant mortality rate (IMR) and under 5 mortality rate (U5MR) (table 1). As long as the IMR and U5MR reduction improves, the rank of the main causes of death and disease changes. In those countries with high IMR, perinatal health problems are followed by acute respiratory infections and congenital malformations. In those countries with lower IMR rates, prematurity, congenital malformations and complications during early neonatal period become the main causes. Significant U5MR reductions were achieved by Peru and Brazil as a consequence of the utilisation of measures that impact in life conditions and integrated management of childhood illnesses. Average country reductions mask the existing inequity gaps within countries. For example, the IMR ratio between indigenous and non-indigenous populations ranges from 1.11 in Chile to 2.3 in Ecuador.

Table 2 shows those health problems related to communicable, maternal, neonatal, and nutritional disorders and injuries that affect young populations. ${ }^{2}$ The region is divided into three subregions (Andean, Tropical and Southern). Colombia and Venezuela are considered separately. Epidemiological transition is represented as a trend of first ranked health problems for 1990 and 2010. Using an arrow diagram, trends can show no variation, increase or decrease in magnitude. Colombia and Venezuela show similar profiles to Southern countries with interpersonal violence as a highly ranked health problem. Changes in child health paradigms are also the result of new transitions such as moving from inter-sectoral approaches to Health in All Policies. ${ }^{3}$

\section{THE RIGHT TO CHILD HEALTH}

Guaranteeing children the right to health ${ }^{4}$ includes state actions on the determinants of health (balanced nutrition, quality housing, essential public services, decent work for parents, basic sanitation, including water, healthy environment, education, clothing and appropriate health services across the life span).
All the countries in South America have signed the major declarations and agreements on human rights. States have the obligation to respect, ensure and protect the right to health, which includes: not advancing or promoting policies or actions (by any sector of the state) that adversely affect in any way the health of children; providing resources and means necessary to achieve the guaranteed right to health; adopting policies, plans, programmes, strategies and actions of both the health sector and other sectors involved in the promotion and care of child health; protecting children and adolescents from any situation that violates or affects their right to health by any member of society or the state itself; preventing discrimination and adopting legislative means and differentiating political actions for the most vulnerable groups; monitoring compliance of the other actors who share responsibility for child health such as the family and society and immediately restoring rights when violations have occurred; discouraging and punishing violations of the right to individual or collective health committed by public servants, or by any citizen, company or institution.

Traditionally, women's rights and children rights are considered as separate issues and agendas. We know that both women (mothers) and children's rights are interdependent. Assuring and respecting sexual and reproductive rights constitute a starting point to protecting the rights of children. More than $50 \%$ of pregnant women in South America become mothers as a consequence of unwanted or unplanned decisions, some of them after sexual abuse. It is expected that every child that is born in the region will be the result of an adult, responsible negotiation on the best time to become parents.

\section{PRIORITY CONCERNS IN SOUTH AMERICA}

The health sector reforms that have taken place in Latin America have privatised the management and delivery of health services, often turning services into commodities, limiting established rights provisions in a contract. As a result, there has been a worrying fragmentation of health services. Health is not considered as an integral theme today, but rather, one that is divided into different market niches, each of which has its own interests.

Financial groups see the health sector as a business. As such, they have monopolised the market for vaccines, drugs and diagnostic and therapeutic support, leading to high costs that are not accessible to most of poor population.

Although primary care has improved, it is limited in coverage, quality and timeliness. This has generated a situation where most of the states' resources are invested in addressing health problems that could have been prevented. 
Figure 1 The South American region.

The South American Region

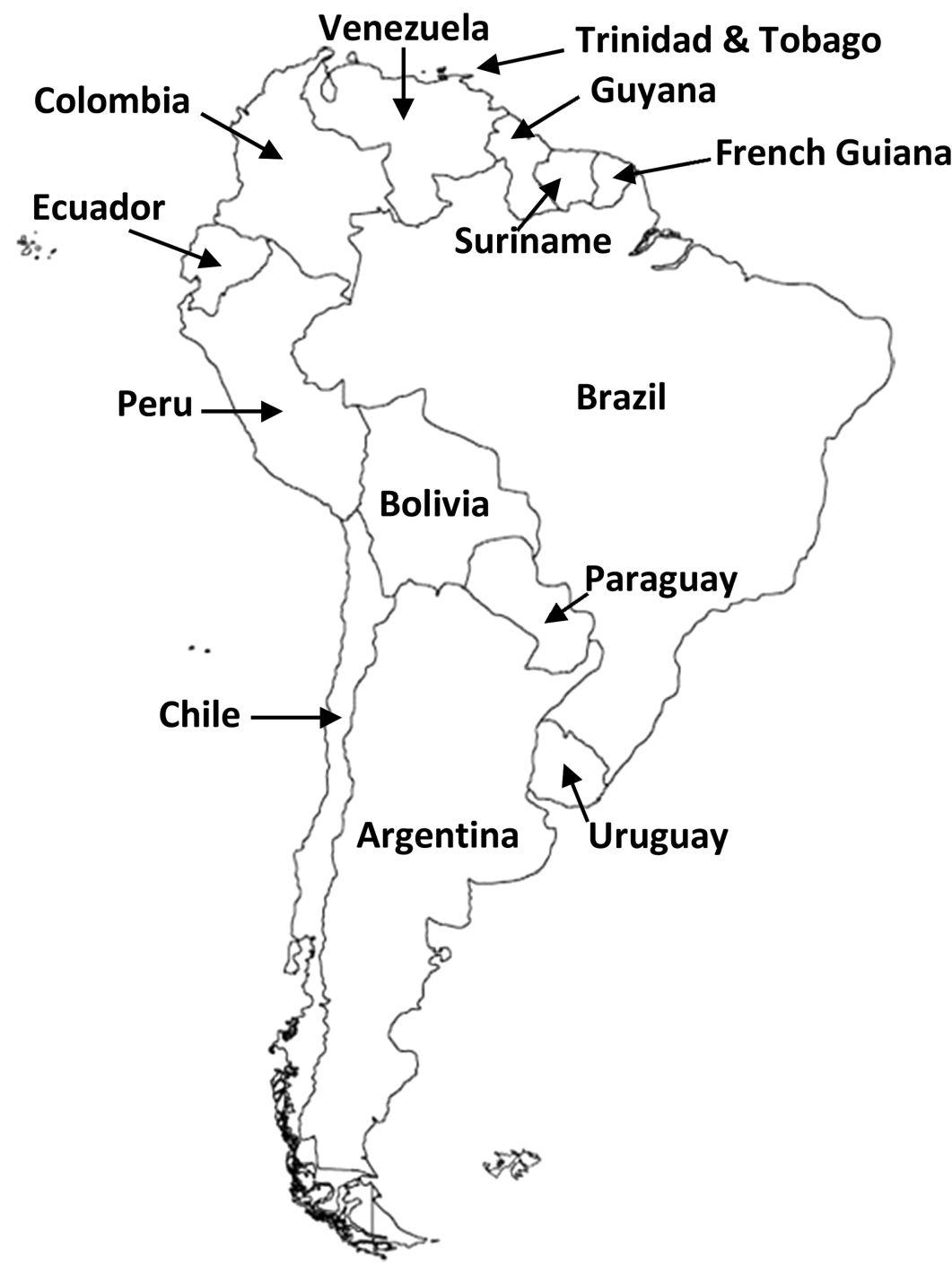

Concern in the region is focused on the problems of chronic malnutrition (stunting), iron-deficiency anaemia, obesity (the new face of poverty), low birth weight, congenital problems, perinatal problems, acute respiratory illness and acute diarrhoeal

Table 1 Overall reduction (\%) of infant mortality rate (IMR*) and under 5 mortality rate (U5MRt) in South America (1990-2010)

\begin{tabular}{lllllll}
\hline Country & $\begin{array}{lllll}\text { IMR } \\
\text { B IMR }\end{array}$ & $\begin{array}{l}\text { Percentage } \\
\text { of reduction }\end{array}$ & $\begin{array}{l}\text { U5MR } \\
1990\end{array}$ & $\begin{array}{l}\text { U5MR } \\
\mathbf{2 0 1 0}\end{array}$ & $\begin{array}{l}\text { Percentage } \\
\text { of reduction }\end{array}$ \\
\hline Bolivia & 84 & 42 & -50 & 123 & 45 & -63 \\
Peru & 55 & 15 & -73 & 79 & 20 & -75 \\
Brazil & 50 & 17 & -66 & 62 & 16 & -75 \\
Ecuador & 41 & 18 & -56 & 56 & 25 & -56 \\
Paraguay & 40 & 21 & -48 & 46 & 24 & -48 \\
Venezuela & 31 & 12 & -61 & 31 & 16 & -48 \\
Colombia & 30 & 17 & -43 & 35 & 19 & -46 \\
Argentina & 24 & 12 & -50 & 28 & 15 & -46 \\
Chile & 16 & 8 & -50 & 19 & 9 & -53 \\
Uruguay & 20 & 9 & -55 & 23 & 9 & -61 \\
\hline
\end{tabular}

disease, dental problems, developmental problems, disabilities, mental health problems, accidents and violence. Unwanted and unintended teen pregnancies persist with the associated morbidity and mortality for both mothers and their offspring, psychoactive substance use, sexual and reproductive health of adolescents and HIV-AIDS and other sexually transmitted diseases. Of equal importance is the concern for an effective guarantee of child rights in situations of natural disasters.

Adverse child conditions are expressed under multiple forms of violence that include abandonment, child labour, slavery, begging, street life, sexual abuse and exploitation, linking criminal gangs and armed groups, abduction, trafficking and use in the production and trade of narcotics and all forms of discrimination, including gender stereotyping and early gender violence.

Social participation in health in the region is treated in a utilitarian manner through a series of consultative councils that are non-binding and aimed at controlling and monitoring the effective guarantee of the right to health.

\section{WINDOW OF OPPORTUNITIES}

This new millennium offers possibilities in terms of policy formulation that were never considered before. Most representative 
Table 2 Global burden of disease 2010 arrow diagram in South America

\begin{tabular}{|c|c|}
\hline \multicolumn{2}{|c|}{ Andean Latin America: Bolivia, Ecuador, Peru } \\
\hline 1990 Rank & 2010 Rank \\
\hline 1.Lower respiratory infections & 1. Lower respiratory infections \\
\hline 2.Diarrheal diseases & 2. Road injury \\
\hline \multicolumn{2}{|l|}{ 3.Preterm birth complications } \\
\hline \multicolumn{2}{|l|}{ 4.Iron-deficiency anemia } \\
\hline \multicolumn{2}{|l|}{ 5.Neonatal encephalopathy } \\
\hline 6.Tuberculosis & 6. Preterm birth complications \\
\hline 7.Road injury & 7.Iron-deficiency anemia \\
\hline 8.Protein-energy malnutrition & 8.Diarrheal diseases \\
\hline 9.Congenital anomalies & 9.Neonatal encephalopathy \\
\hline 13. Neonatal sepsis & 10.Congenital anomalies \\
\hline \multirow[t]{4}{*}{ 15. Syphilis } & 15. HIV/AIDS \\
\hline & $\begin{array}{l}\text { 18. Neonatal sepsis } \\
\text { 21. Tuberculosis }\end{array}$ \\
\hline & 35. Protein-energy malnutrition \\
\hline & 50. Syphilis \\
\hline \multicolumn{2}{|l|}{ 62. HIV/AIDS } \\
\hline \multicolumn{2}{|c|}{ Tropical Latin America: Brazil, Paraguay } \\
\hline 1990 Rank & 2010 Rank \\
\hline \multicolumn{2}{|l|}{ 1.Preterm birth complications } \\
\hline \multicolumn{2}{|l|}{ 2.Lower respiratory infections } \\
\hline \multicolumn{2}{|l|}{ 3.Diarrheal diseases } \\
\hline & 5. Road injury \\
\hline 7. Road injury & 7. Lower respiratory infections \\
\hline 9. Neonatal encephalopathy & 9.Preterm birth complications \\
\hline 11. Congenital anomalies & 11. HIV/AIDS \\
\hline 12. Iron-deficiency anemia & 12. Congenital anomalies \\
\hline \multicolumn{2}{|l|}{ 14. HIV/AIDS } \\
\hline \multicolumn{2}{|l|}{ 15. Neonatal sepsis } \\
\hline & 18. Iron-deficiency anemia \\
\hline \multirow[t]{4}{*}{ 20. Meningitis } & 20. Neonatal encephalopathy \\
\hline & 25. Diarrheal diseases \\
\hline & 29. Neonatal sepsis \\
\hline & 51. Meningitis \\
\hline \multicolumn{2}{|c|}{ Southern Latin America: Argentina, Chile, Uruguay } \\
\hline 1990 Rank & \begin{tabular}{|r|}
2010 Rank \\
\end{tabular} \\
\hline \multicolumn{2}{|l|}{ 3. Preterm birth complications } \\
\hline \multicolumn{2}{|l|}{ 4. Lower respiratory infections } \\
\hline \multirow[t]{2}{*}{ 5. Congenital anomalies } & 5. Road injury \\
\hline & 6. Lower respiratory infections \\
\hline \multicolumn{2}{|l|}{ 8. Road injury } \\
\hline & 11. Preterm birth complications \\
\hline & 12. Congenital anomalies \\
\hline \multicolumn{2}{|l|}{ 18. Iron-deficiency anemia } \\
\hline \multicolumn{2}{|l|}{ 19. Diarrheal diseases } \\
\hline 23. Neonatal encephalopathy & 27. Iron-deficiency anemia \\
\hline \multirow{4}{*}{ 37. Neonatal sepsis } & 33. HIV/AIDS \\
\hline & 40. Neonatal encephalopathy \\
\hline & 43. Diarrheal diseases \\
\hline & 51. Neonatal sepsis \\
\hline 61. HIV/AIDS & \\
\hline
\end{tabular}


countries in South America developed their own National Child Policies (i.e. Colombia, Brazil, Chile, Uruguay, Ecuador and Bolivia), while others are in the process of doing so. Structural social determinants of health are considered as the cornerstone for policy implementation. In this sense, long-term interventions should be developed as a mode to overcome the traditional reparation model of health and disease.

\section{FINAL COMMENTS}

- Post-2015 agenda should be a consequence of the recognition of the particular situation of each country and local realities.

- Although infant mortality persists as a public health problem, efforts should be made to assure better quality of life for the majority that survives.

- Combating child poverty as a major social determinant of health is the key entry point to reducing the existing health and social inequities.

- Early child development policies promoting equity from the start intimate the need to consider long-term interventions to assure better social living conditions.

- Environmental degradation affects mostly children and, among them, poor kids are the most vulnerable. ${ }^{5}$

- Improving environmental quality includes, among other actions, urban planning, safe transportation and public spaces for recreation.
- The right to child health is a responsibility of the states that must be protected, respected and fulfilled.

- Children should be recognised as subjects of rights, promoting universal early inclusive citizenship and empowerment from the time of their birth.

Contributors RM was responsible of planning, conduct and reporting of the content described in the article.

Competing interests None.

Provenance and peer review Commissioned; internally peer reviewed.

\section{REFERENCES}

1 Waitzkin $H$, Iriart C, Estrada $A$, et al. Social medicine then and now: lessons from Latin America. Am J Public Health 2001;91:1592-601.

2 Institute for Health Metrics and Evaluation. Global burden of disease. http://vizhub. healthdata.org/irank/arrow.php (accessed 24 Jun 2014).

3 Mercer $\mathrm{R}$, Hertzman $\mathrm{C}$, Molina $\mathrm{H}$, et al. Promoting equity from the start through early child development and Health in All Policies (ECD-HiAP). In: Health In All Policies. Seizing opportunities, implementing policies. Chapter VI. Ministry of Social Affairs and Health, Finland, 2013. http://www.euro.who.int/_data/assets/pdf_file/0007/ 188809/Health-in-All-Policies-final.pdf. (accessed 24 Jun 2014).

4 Committee on the Rights of the Child. General comment No. 15 (2013) on the right of the child to the enjoyment of the highest attainable standard of health (art. 24). http://www2.ohchr.org/english/bodies/crc/docs/GC/CRC-C-GC-15_en.doc (accessed 24 Jun 2014).

5 Goldhagen J, Mercer R. A child rights and equity based assessment of the impact of global climate change on children's health and well-being. Int Public Health J 2010;2541-51 http://api.ning.com/files/ojSCGs3jvX3gZOlsLcTx0LnaCaglaOKalUA3 JCeNYo4myDQLKZyWILeCTLORPJ-S6u65to-CZ2r8N9CVW3mMxcpCPIXUnH8|/ CRandclimatechangeGoldhagen_Mercer.pdf (accessed 24 Jun 2014). 